\title{
SYNERGISTIC EFFECT OF DIFFERENT PLANT EXTRACTS AND ANTIBIOTICS ON SOME PATHOGENIC BACTERIA
}

\author{
Suzan A. Shareef ${ }^{\mathrm{a}, *}$, Abdulilah S. Ismaeil ${ }^{\mathrm{b}}$, Akhter A. Ahmad ${ }^{\mathrm{b}}$ \\ ${ }^{\text {a }}$ Dept. of General Sciences, College of Basic Education, Salahaddin University, Kurdistan Region, Iraq- \\ (suzan.sharif@su.edu.krd) \\ ${ }^{\mathrm{b}}$ Dept. of Biology, College of Science, Salahaddin University, Kurdistan Region, Iraq- (abdulilah.ismaeil; akhter.ahmed) \\ @su.edu.krd
}

\begin{abstract}
:
In this study, the antibacterial activity of methanol extract of henna (Lawsonia inermis) leaves, ethanol extract of pomegranate (Punica granatum) peel, volatile oil of sesame Sesamum indicum) and peanut (Arachis hypogaea) were investigated against some Gram-positive and Gram-negative bacteria including Staphylococcus aureus, Bacillus cereus, Escherichia coli and Acinetobacter $s p$. Henna extract was most effective substrate against all tested bacteria followed by pomegranate and peanut while sesame was less effective. All extracts were screened for their antibacterial adivity in combination with commonly used antibiotics, including ciprofloxacin and erythromycin to evaluate synergistic effects using Minimum inhibitory concentrations (MIC) method which determined by microbroth dilution assays. Different interactions (syne rgistic and indifference) were observed between plant extracts and used antibiotics. The fractional inhibitory concentration (FIC) index ranged from 0.01 to 1.25 for $B$. cereus, 0.5 to 1 for $P$. aeruginosa, 0.01 to 0.3 for $S$. aureus and 0.06 to 0.25 for $A$. baumannii. The best synergistic capacity appeared between erythromycin and sesame. In vitro interaction between antimicrobial agents in combination with tested plant extracts showed synergistic effects. The MICs of each antibiotic was decreased to half when it is used in combination with tested plant extracts. This decreasing inMICs was observed in all plant extracts against tested bacteria as well as the extracts exhibited weak antibacterial activity alone.
\end{abstract}

KEYWORDS: Antibacterial activity; Combination;Minimum inhibitory concentration (MIC); Plant extract; Synergistic.

\section{INTRODUCTION}

Infectious diseases caused by bacteria and fungi affect millions of people worldwide. Throughout the history of mankind, infectious diseases have remained a significant cause of death and disability; it accounts for one-third of all deaths in the world (Us ha et al., 2010). The discovery of antibiotics was an essential part of combating bacterial infections that once ravaged humankind (Ushaet al., 2010). Antibiotics are critical weapons in combating bacterial infections and can be beneficial for human heath (Berge and Wierup, 2012). However, overtime, the effect of antibiotics that routinely used have decreased against certain infections due to production of toxic reactions and the development of resistant strains of bacteria (DiMasi et al, 2016). The rapi d development of drug-resistant bacteria is an important health problem that occurred worldwide (Rouveix, 2007 and Ahmed, 2013). The alarming growth of the number of antibiotic resistant bacteria and difficulties in treatment of infections, besides sometim es antibiotics use may cause opposite effects, such as allergic reactions, immune destruction, and hypersensitivity have initiated a search for new antibacterial compounds and develop new alternative strategies in combating bacterial infections (Agrawal et al., 1996). Medicinal plants, with their long history of use in folk medicine for the treatment of infectious diseases, have become a promising innovative antimicrobial substances by extraction of phytochemicals, which are active to prevent infections (Abiramasundari et al., 2011 and Agrawal et al., 1996). Plant -derived compounds could exhibit a direct antibacterial activity and/or an indirect activity as antibiotic resistance modifying compounds, which, combined with antibiotics, increase their effectiveness (Haroun and Al-Kayali, 2016).

The use of plant extracts can be highly significant in therapeutic treatments and there are many different medicinal plants used in traditional medicine by the traditional herbalists to treat varieties of human ailments(Aali et al., 2018). Numbers of different plants have been used due to their antimicrobial activity as a result of their active substances while others by a combination of their common phytochemicals with antibiotics (Ahmed et al., 2010). For this reason, the antibacterial activities of plant extract alone and when it combined with different antibiotics have been studied in many parts of the world by a number of researchers. Farooqui et al . (2015) investigated synergistic antimicrobial activity of Camelliasinensis and Juglans regia with nalidixic acid against 350 Gram-positive and Gram-negative strains belonging to 10 different bacterial species. While Liu et al. (2017) studied synergistic antimicrobial effect of lipopeptides and tea polyphenols against $V$. parahaemolyticus and their result showed that the combination of lipopeptides and tea polyphenols displayed strong synergistic antibacterial effect against parahaemolyticus with a fractional inhibitory concentration index of 0.19. In another study by Ennacerie et al. (2017) also tested the antibacterial potency and evaluate the possible synergistic effect between both aqueous and ethanolic extracts, flower buds and fruits of Capparis spinosa, and antibiotics against Klebsiella pneumoniae and Pseudomonas aeruginosa and their results showed a synergistic effect with ICIF ranging from 0.02 to 0.24 . From the points of view, the present study

\footnotetext{
* Corresponding author

This is an open access under a CC BY -NC-SA 4.0 license (https://creativecommons.org/licenses/by -nc-sa/4.0/)
} 
conducted to investigate whether the combination of some plant extracts with commonly used antibiotics has any synergistic effects on some clinically isolated bacteria or not.

\section{MATERIALS AND METHODS}

\section{1. Plant materials and extraction}

Henna (Lawsonia inermis) leaves, pomegranate (Punica granatum) peel, Peanut (Arachis hypogaea) and Sesame (Sesamum indicum) were selected as medicinal plants for extraction.

The plant materials were processed by the methods described previously by (Harborne, 1998). Briefly, pulverized plant material (after cleaning and shade drying) was extracted using normal hexane, methanol, and ethanol as solvents. To remove the solvents from the extracts vacuum evaporator was used to attain the crude extract of each fraction. The extracts stored at $-20{ }^{\circ} \mathrm{C}$ and freshly dissolved in dimethyl sulfoxide (DMSO, Merk Germany) before use.

2.1.1. Extraction of henna leaf: Fifty grams of henna leaves were dried under shade, milled and extracted with n-hexane by the use of Soxhlet extractor apparatus for about six hours. Extraction was carried out the color of the solvent in the last siphoning time became colorless. Then, the solvent evaporated under reduced pressure by the use of a rotary evaporator apparatus. The marc obtained from henna was shade dried and re-extracted with methanol using the above method.

2.1.2. Extraction of Pomegranate Peel: Fifty grams of Pomegranate dry powder was mixed with ethanol, sonicated, and filtered by Whatman paper no.1. The supernatant was dried by rotary evaporator.

2.1.3. Volatile oil of sesame and peanut: One hundred grams of both sesame and peanut weighted were put in 2000 $\mathrm{ml}$ rounded bottom capacity flask, separately. Both Clevenger receiver and condenser were attached to the top of the flask, $1000 \mathrm{ml}$ of distilled water was added. The system was heated to $100^{\circ} \mathrm{C}$ for about $4 \mathrm{~h}$ until the oil volume at the upper part of the receiver fixed. The oil was pipetted and dried over sodium sulfate anhydrous. Then, it was stored in a dark container in the refrigerator till used (Harborne, 1998).

\subsection{Preparing of oil concentrations}

Each plants extract was dissolved in dimethyl sulfoxide (DMSO) (50\% of the final volume) and was then diluted with Tryptic Soy Broth medium (TSB; Oxoid) to concentrations $(2,4,8,16,32,64,128) \mathrm{mg} / \mathrm{ml}$.

\subsection{Antimicrobials}

Pure antimicrobial powders of Ciprofloxacin and Erythromycin were selected as antimicrobials in this study. The stock solution was prepared by dissolving the powder in TSB in different concentrations $(2,4,8,16,32,64,128)$ $\mathrm{mg} / \mathrm{ml}$ (Lalitha, 2004).

\subsection{Bacterial isolates}

Clinical isolates investigated in this study were; Acinetobacter baumannii and Pseudomonas aeruginosa as Gram-negative, Bacillus cereus and Staphylococcus aureus as Gram-positive (The isolates were obtained from Bacteriology laboratory of West Emergency Hospital in Erbil City. Vitek II automated system (bioMérieux Marcy l'Etoile, France) (Vitek Systems Version: 06.01) was used to identify the isolates.

\subsection{Minimum inhibitory concentration (MIC) determination}

Broth microdilution assay was performed to determine the minimum inhibitory concentration for the galls extracts against the identified isolates (Roberts et al., 2012). Ten $\mu$ l of bacterial cells (equilibrated to OD550 0.5) inoculated into $100 \mu \mathrm{L}$ TSB containing a range of extracts or antimicrobials concentrations beginning (1-128 mg ml-1) in the polystyrene microtiter plate (MTP) wells. The MTPs have incubated overnight at $37^{\circ} \mathrm{C}$. The lowest concentration that did not show any obvious growth was considered as minimum inhibitory concentration. To determine the minimum bactericidal concentration, $100 \mu 1$ from MTP wells that did not show any obvious growth was streaked on sterile plates of nutrient agar (NA; Oxoid). Nutrient agar (NA) plates were incubated overnight at $37^{\circ} \mathrm{C}$. Concentrations that have no growth on NA plates were considered as minimum bactericidal concentration (MBC). The level below the MICs was considered as subinhibitory concentrations (SICs) which then used to evaluate the synergistic effect of the extracts with antimicrobials. Three replicates were considered on distinct occasions.

\subsection{Checkerboard technique to determine the synergistic antimicrobial activity}

To investigate the effect of the combination of each extract with the selected antimicrobials $150 \mu \mathrm{L}$ of TSB medium containing a mixture of SIC of each plant extract and each of the tested antimicrobials were added to 96-well microtiter plates, TSB with no extract and antimicrobials was used as a control. The wells were inoculated with $10 \mu \mathrm{L}$ of a bacterial suspension. All experiments were achieved in triplicate, and the MTP was incubated overnight at $37^{\circ} \mathrm{C}$. To determine the synergistic effect of the extracts and the antimicrobials the broth in the wells were sub-cultured on NA plates.

The combination between the extracts and the antibiotics were evaluated by the checkerboard method as described by Petersen et al (2006). The fractional inhibitory concentration (FIC) was derived from the lowest concentrations of the extract in tryptic soy broth tube after overnight incubation at $37{ }^{\circ} \mathrm{C}$. FICs were calculated using the following formula:

$$
\begin{gathered}
\left.\sum \text { FIC (FIC index }\right)=\frac{\text { MIC of plant extract in combinatior }}{\text { MIC of plant extract alone }} \\
\sum \text { FIC (FIC index) }=\frac{\text { MIC of plant extract in combinatior }}{\text { MIC of plant extract alone }}+ \\
\frac{\text { MIC of antibiotics in combinationMIC of antibiotics in combination }}{\text { MIC of antibiotics alone }}
\end{gathered}
$$

When antibiotic combined with a plant extract, synergy is happened when FIC index $\leq 0.5$, additivity when $5<$ index FIC $\leq 1$, indifference when $1<$ FIC index $\leq 4$ and antagonism when FIC index $>4$ as described by Petersen et al. (2006). While Kamatou et al (2006) defined synergy that happened when FIC inde $<1.0$, additivity when FIC index $=1.0$ and antagonism when FIC index $>1.0$. Hence, due to checkerboard assay, Olajuyigbe and Afolayan (2012) indicated that synergy is determined when FIC is less than or equal to 0.5 or is less than or equal to 1 .

\subsection{Statistical data analysis}

All the data were analyzed by Statistical Package Social Science (SPSS) version 21.0. The experimental results were expressed as mean \pm standard error of the mean (SEM). Groups were compared by analysis of variance using Two-way ANOVA and Dunnett's multiple comparisons test. Less than 0.05 of $p$-value was regarded as statistically significant. Significance was defined as $\mathrm{p}<0.05, \mathrm{p}<0.01$. 


\section{RESULTS}

The Minimum inhibitory concentration (MIC) of plant extracts alone, and antibiotics alone were examined against tested bacteria, as shown in Table (1), Figure (1).

Ciprofloxacin showed inhibited active on bacterial species at $(4 \mathrm{mg} / \mathrm{ml})$ against all tested bacteria while erythromycin was more active and inhibited tested bacteria at $1 \mathrm{mg} / \mathrm{ml}$ except S. aureus $(2 \mathrm{mg} / \mathrm{ml})$.

The antibacterial activities of the plant extract varied in relation to the tested organisms. Henna extract was the most effective against all tested bacteria. The most active concentration was $4 \mathrm{mg} / \mathrm{ml}$ concentration that inhibited the growth of Staphylococcus aureus, Acinetobacter baumannii and Bacillus cereus utterly, while Pseudomonas aeruginosa was inhibited by $8 \mathrm{mg} / \mathrm{ml}$ concentration of henna extract.

Pomegranate also showed antibacterial activity with different concentrations against all tested bacteria. Most effective concentration was $4 \mathrm{mg} / \mathrm{ml}$ against $P$. aeruginosa, $16 \mathrm{mg} / \mathrm{ml}$ against Acinetobacter while $S$. aureus and B. cereus were inhibited at a minimum inhibitory concentration of $32 \mathrm{mg} / \mathrm{ml}$. Peanut showed similar effects to that of henna against $P$. aeruginosa at MIC of $8 \mathrm{mg} / \mathrm{ml}$ and $A$. baumannii at MIC of $4 \mathrm{mg} / \mathrm{ml}$, while it was less effective against $B$. cereus at MIC of $32 \mathrm{mg} / \mathrm{ml}$.

Table 1. Minimum inhibitory concentration (MIC) of plant extracts alone and antibiotics alone against tested bacteria

\begin{tabular}{|c|c|c|c|c|}
\hline \multirow{2}{*}{$\begin{array}{l}\text { Antibiotic and } \\
\text { Plant extract }\end{array}$} & \multicolumn{4}{|c|}{ MIC (mg/ml) } \\
\hline & $\begin{array}{c}S . \\
\text { aureus }\end{array}$ & $\begin{array}{c}\text { B. } \\
\text { cereus }\end{array}$ & $\begin{array}{c}P . \\
\text { aeruginosa }\end{array}$ & $\begin{array}{c}A . \\
\text { baumannii }\end{array}$ \\
\hline $\begin{array}{c}\text { Henna } \\
\text { (Lawsonia inermis) }\end{array}$ & 4 & 4 & 8 & 4 \\
\hline $\begin{array}{c}\text { Pomegranate } \\
\text { (Punica granatum) } \\
\end{array}$ & 32 & 32 & 4 & 16 \\
\hline $\begin{array}{c}\text { Peanut } \\
\text { (Arachis hypogaea) }\end{array}$ & 64 & 32 & 8 & 4 \\
\hline $\begin{array}{c}\text { Sesame } \\
\text { (Sesamum indicum) }\end{array}$ & 128 & 64 & 64 & 32 \\
\hline Ciprofloxacin & 4 & 4 & 4 & 4 \\
\hline Erythromycin & 2 & 1 & 1 & 1 \\
\hline
\end{tabular}

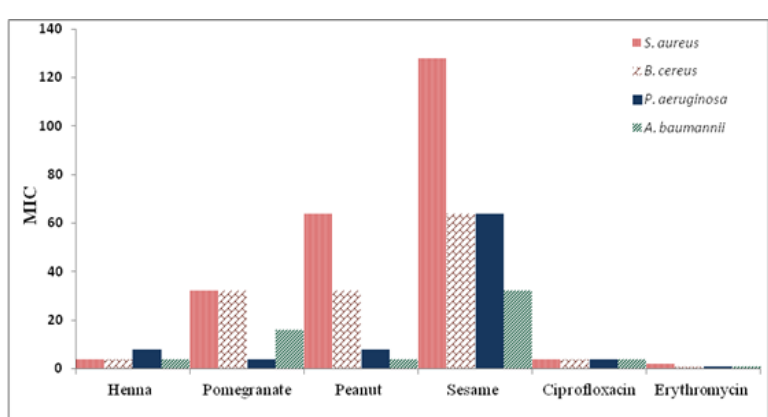

Figure 1. Minimum inhibitory concentration (MIC) of plant extracts alone and antibiotics alone against tested

In vitro interaction between antimicrobials and tested plant extracts by microdilution method showed a reduction of MIC of the antimicrobials when combined with plant extracts. The minimum inhibitory concentration of antibiotics in combination with plant extracts against pathogenic bacteria tested by microdilution method is shown in Table [2].

Table 2. Minimum inhibitory concentration of antibiotics in combination with plant extracts against tested bacteria using the microdilution method

\begin{tabular}{|c|c|c|c|c|}
\hline $\begin{array}{c}\text { Antibiotic and } \\
\text { Plant extract } \\
\text { combination }\end{array}$ & S. aureus & $\begin{array}{c}\text { B. } \\
\text { cereus }\end{array}$ & $\begin{array}{c}\text { P. } \\
\text { aeruginosa }\end{array}$ & $\begin{array}{c}A . \\
\text { baumannii }\end{array}$ \\
\cline { 2 - 5 } Cip + Sesame & $2: 64$ & $\mathrm{~N}$ & $\mathrm{~N}$ & $\mathrm{~N}$ \\
\hline Cip + Henna & $\mathrm{N}$ & $2: 2$ & $2: 4$ & $2: 2$ \\
\hline
\end{tabular}

\begin{tabular}{|c|c|c|c|c|}
\hline $\begin{array}{c}\text { Cip }+ \\
\text { Pomegranate }\end{array}$ & $\mathrm{N}$ & $\mathrm{N}$ & $2: 2$ & $2: 8$ \\
\hline Cip + Peanut & $\mathrm{N}$ & $2: 16$ & $\mathrm{~N}$ & $\mathrm{~N}$ \\
\hline Ery + Sesame & $1: 64$ & $0.5: 32$ & $\mathrm{~N}$ & $\mathrm{~N}$ \\
\hline Ery + Henna & $\mathrm{N}$ & $\mathrm{N}$ & $\mathrm{N}$ & $\mathrm{N}$ \\
\hline $\begin{array}{c}\text { Ery }+ \\
\text { Pomegranate }\end{array}$ & $\mathrm{N}$ & $\mathrm{N}$ & $\mathrm{N}$ & $\mathrm{N}$ \\
\hline Ery + Peanut & $\mathrm{N}$ & $0.5: 16$ & $\mathrm{~N}$ & $\mathrm{~N}$ \\
\hline
\end{tabular}

$\mathrm{N}=$ No effect

Antibacterial combination considered as synergism in $\sum \mathrm{FIC} \leq$ 1.0 , indifference in $1.0<\sum \mathrm{FIC} \leq 4$ and antagonism in $\sum \mathrm{FIC}>4$ [Table 3]. According to the standard evaluation measures of Kamatou et al. (2006) and Grytten et al. (1988). In combination between ciprofloxacin and henna leaf extract, the MIC of ciprofloxacin was reduced from $4 \mathrm{mg} / \mathrm{ml}$ to $2 \mathrm{mg} / \mathrm{ml}$ and showed synergistic interaction against $P$. aeruginosa and Acinetobacter ( $\sum \mathrm{FIC}$ is less than or equal to 1.0), while it was indifference (1.0 $<\sum$ FIC $\leq 4$ ) against $B$. cereus. The MIC of henna leaf extract was decreased from 4, 8, $4 \mathrm{mg} / \mathrm{ml}$ to $2,4,2 \mathrm{mg} / \mathrm{ml}$ against $B$. cereus, $P$. aeruginosa and Acinetobacter respectively. The combination interaction between ciprofloxacin with pomegranate (against $P$. aeruginosa and Acinetobacter) and peanut (against B. cereus) showed a significant reduction of MIC for both antibiotic and plant extract and the combination was classified as synergy $\left(\sum \mathrm{FIC} \leq 1.0\right)$. Erythromycin and sesame activity against $S$. aureus and $B$. cereus also were more effective when combined together and reduced the MIC against these bacteria while no synergistic effect of them was produced against the other tested bacteria. No significant reduction of MIC occurred in combination between erythromycin and both henna and pomegranate, while there was a synergistic effect of the combination of erythromycin and peanut and the MICs of both of them decreased against $B$. cereus.

Table 3. Fractional inhibitory concentrations (FIC) of different combination of the extracts and the antibiotics.

\begin{tabular}{|c|c|c|c|}
\hline \multirow{2}{*}{$\begin{array}{l}\text { Antimicrobials } \\
\text { and Plant } \\
\text { extract } \\
\text { combination }\end{array}$} & \multicolumn{3}{|c|}{ Fractional Inhibitory Concentration } \\
\hline & $\begin{array}{c}\text { Tested } \\
\text { bacteria }\end{array}$ & FIC index & Remarks \\
\hline Cip + Henna & B. cereus & 1.25 & Indifference \\
\hline Cip + Henna & P. aeruginosa & 0.5625 & Synergy \\
\hline Cip + Henna & A. baumannii & 0.0625 & Synergy \\
\hline Cip + Peanut & B. cereus & 0.12890625 & Synergy \\
\hline $\begin{array}{c}\text { Cip }+ \\
\text { Pomegranate }\end{array}$ & P. aeruginosa & 1 & Indifference \\
\hline $\begin{array}{c}\text { Cip }+ \\
\text { Pomegranate }\end{array}$ & A. baumannii & 0.25 & Synergy \\
\hline Cip + Sesame & S. aureus & 0.3149414 & Synergy \\
\hline Ery + Peanut & B. cereus & 0.0317383 & Synergy \\
\hline Ery + Sesame & S. aureus & 0.015625 & Synergy \\
\hline Ery + Sesame & B. cereus & 0.015625 & Synergy \\
\hline
\end{tabular}

Cip= Ciprofloxacin, Ery = Erythromycin 


\section{DISCUSSION}

Many studies have been reported, assuring the antimicrobial activities of an individual or combined extracts of medicinal plants. In this study, henna extract was more effective against all tested bacteria than the other plant extracts. Henna has many traditional and commercial uses, the most common being as a dye for hair, skin and fingernails because it contains Lawsone (2-hydroxynaphthoquinone) which is one of the component with (0.5-1.5\%) responsible for dyeing. It also contains tannic acid, mucilage, gallic acid and mannite (Kelmanson et al., 2000). The antimicrobial effect of henna may be according to numerous free hydroxyls which are able to combine with the bacterial cell wall structures including carbohydrates and proteins as suggested by Harborne and Baxter (1995) and they attributed that to their attachment to enzyme site rendering them inactive.

Results of the present study showed that pomegranate peel extract was effective against tested bacteria. In particular, among plants, Punica granatum used in traditional medicine, is known for its pharmacological properties that have been evaluated due to antiparasitic, antibacterial, antifungal, antiproliferative, apoptotic, and anticancer effects (Jurenka, 2008). Literature data reported that extracts of Punica granatum peel in different concentrations were effective against different bacterial species such as $S$. aureus, $E$. coli, Salmonella enterica, Shigella sonnei, Enterococcus faecalis, and Bacillus subtilis (Pagliarulo et al., 2016; Subramaniam et al, 2012; Rosas-Burgos et al, 2017 and Dey et al, 2015). Pomegranate beverage contains several compounds that are responsible for the antimicrobial activity, depending on their abundance such as tannins which are considered to be toxic to microorganisms (Viuda-Martos et al., 2010). Their hydrophilic site cooperates with the polar region of the bacterial cell membrane, while the hydrophobic site is immersed in the non-polar region of the bacterial membrane, this affects transporting of substances into the cell (Cristani et al., 2007). Likewise, Naz et al. (2007) suggested a phenolic toxicity through reactions with sulfhydryl groups or through more non-specific interactions with proteins leading to loss of function.

Sometimes the use of antibiotic alone does not give the desired inhibitory effects, this can be defeated by a combination of drugs which appears their synergistic effect, and this is more significant than their effects alone (Kamatou et al, 2006). Synergism is defined as a positive interaction created when two agents are combined and together they exert an inhibitory effect (on the targeted organisms) that is greater than the sum of their individual effects (Levinson and Jawetz, 2002). Consequently, mixing plant extracts with antibiotics enhanced and synergized their effect and decreased their MICs and this fact has clearly emerged in this study. The synergistic effect could be related to the formation of complex chemical products that can be greatly effective to inhibit many species of microorganisms by preventing cell wall to synthesize or may lead to lyses and finally, it dies (Chanda and Rakholiya, 2011). There was a significant synergistic effect of combination between both ciprofloxacin and erythromycin with henna, sesame, pomegranate, and peanut and the MIC of both of them was decreased against tested bacteria and this could be referred to that these crude extracts have many different phytochemicals which might inhibit bacteria by different mechanisms (Duke et al., 2003). This result reveals that plant extracts were potentiating the effects of the ciprofloxacin and erythromycin. This double attack of both agents on different target sites of the bacteria could theoretically lead to either an additive or a synergistic effect (Esimone et al. 2006). In a previous similar study performed by Sato et al (2004), they were combined between methanolic extract of pomegranate and antibiotics and found that the antimicrobial activity of flavonoids and polyphenols when they combined with antibiotics could alter the bacterial resistant properties to be more effective. Cushnie et al (2005) in different study indicated synergism between antibiotics and flavonoids. Tsuchiya et al (1996) reported that flavonoids disrupt bacterial cell membranes while Prasad et al (2008) found that tannins precipitate bacterial protein. Yang et al. (2005) and Aqil et al. (2005) reported in a previous in vitro studies, significant decreasing in the MICs and synergistic effects of the antibiotics when combined with number of plant extracts against Staphylococcus aureus.

Ciprofloxacin is a second generation fluoroquinolone, interrupts DNA replication by inhibiting both topoisomerase II (an enzyme that reduces the amount of supercoiling of the DNA doublestranded helix during the replication process) and IV thus preventing cell division (Grohe et al, 1987). By the way, Liu et al. (2011) stated that flavonoids are exist in many types of our food such as vegetables, and fruits and they are able to combine with fluoroquinolone antibiotics to exhibit an effective antimicrobial agent.

\section{CONCLUSION}

Obtained results confirm the antibacterial activity of henna, pomegranate, peanut and sesame extract and shows their potential use as agents which enhance antibiotic activity. Sometimes mixing plant extracts with different antimicrobials enhanced and increase their antibacterial activity and the antimicrobials that produce side effects can be used by reducing dose concentration exploiting their synergy with the medicinal plants. Mixing plant extracts with antimicrobials also increases the spectrum of antibiotic, avoids the development of resistance and decreases toxicity so exhibiting antibacterial activity better than that estimated from each antibiotic alone. Further studies are required to determine the specific substrates that have synergistic effect and approved with in vivo studies.

\section{REFERENCES}

Ali M.H., Ismaiel N.J., AbdulMajid F.A. (2018). Antioxidant, and Antimicrobial Activities of Phenolic and Flavonoid-Rich Medicinal Plants (Fritillaria zagrica and Tulipa kurdica) Bulbs Collected in Kurdistan Region of Iraq. Zanco Journal of Pure and Applied Sciences, 30(5):1-16.

Abiramasundari P., Priya V., Jeyanthi G.P., Gayathri D.S. (2011). Evaluation of the Antibacterial activity of Cocculus hirsutus. HYGEIA - Journal for Drugs and Medicine, 3(2):26-31.

Agrawal P., Rai V., Singh R., B. (1996). Randomized, placebocontrolled, single-blind trial of holy basil leaves in patients with noninsulin-dependent diabetes mellitus. International Journal of Clinical Pharmacology and Therapeutics, 34:406-9.

Ahmed A. A., Mawlood S.I., Ismaeel A.S. (2010). Role of solvent and methods of extraction on the inhibitory effect of black seed extracts on Pseudomonas aeruginosa. Zanco Journal of Pure and Applied Sciences, 22, 3.

Ahmed, A. A. (2013). In vitro screening of Lactobacillus species from homemade yoghurt for antagonistic effects against common bacterial pathogens. Jordan Journal of Biological Sciences, $6(3): 2011-16$.

Aqil F., Khan M.S.A., Owais M. Ahmad I. (2005). Effect of certain bioactive plant extracts on clinical isolates of -lactamase producing methicillin resistant Staphylococcus aureus. Journal of Basic Microbiology. 45:106-114.

Berge, A. C. and M. Wierup, M. (2012). Nutritional strategies to combat Salmonella in mono-gastric food animal production. Animal, 6: 557-564.)

Chanda, S. and Rakholiya, K. (2011). Combination therapy: Synergism between natural plant extracts and antibiotics against infectious diseases. Science against microbial pathogens: communicating current research and technological advances. Formatex, 1: 520-9.

Cristani M., D'Arrigo M., Mandalari G., Castelli F., Sarpietro M.G., Micieli D., Venuti V., Bisignano G., Saija A., Trombetta D. 
(2007). Interaction of four monoterpenes contained in essential oils with model membranes: implications for their antibacterial activity. Journal of Agricultural and Food Chemistry, 25; 55(15):6300-8.

Cushnie T.P.T., Lamb A.J. (2005). Antimicrobial activity of flavonoids. International Journal of Antimicrobial Agents., 26: 343-56.

Dey D., Ray R. and Hazra B. (2015). Antimicrobial activity of pomegranate fruit constituents against drugresistant Mycobacterium tuberculosis and B-lactamase producing Klebsiella pneumonia (2015). Journal of Pharmaceutical Biology, 53 (10): 1474-80.

DiMasi J.A., Grabowski H.G., Hansen R.W. (2016). Innovation in the pharmaceutical industry: new estimates of R\&D costs. Journal of Health Economics, 47: 20-33.

Drobniewski F.A. (1993). Bacillus cereus and related species. Clin. Microbiol. Rev. 6:324-338.

Duke J. A., JoBojeneschutz-Godwin M., DuCellier J., Duke P.A.K. (2003). CRC, Handbook of Medical Plant. Boca Raton: CRC Press, FL. 348

Ennacerie F-Z., Filali F. R., Najia Moukrad, Ed-Dra A. (2017). Antibacterial synergistic effect of extracts of the organs of capparis spinosa and in combination with antibiotics. International Journal of Advanced Research, 5(9), 1238-47.

Farooqui A., Khan A., Borghetto I., Kazmi S.U., Rubino S., Paglietti B. (2015). Synergistic antimicrobial activity of Camellia sinensis and Juglans regia against multidrug-resistant bacteria. PLoS One, 10:e118431.

Grohe K., Zeiler H.J., Metzger G. (1987). 7-amino-1-cyclopropyl-4oxo-1, 4-dihydro-quinoline and naphthyridine 3-carboxylic acids and antibacterial agents containing these compounds. US patent, 4: 670

Grytten J., Scheie A.A., Giertsen E. (1988). Synergistic antibacteria effects of copper and hexetidine against Streptococcus sobrinus and Streptococcus sanguis. Acta Odontologica Scandinavica, 46:181-3.

Harborne J.B. (1998). Phytochemical Methods A guide to modern techniques of plant analysis. Third Ed: Chapman \& Hall.

Harborne S.B and Baxter A. (1995). Phytochemical Dictionary. A handbook of bioactive compounds from plants. Tylor and Francis. London.

Haroun M. and Al-Kayali R.S. (2016). Synergistic effect of Thymbra spicata $L$. extracts with antibiotics against multidrugresistant Staphylococcus aureus and Klebsiella pneumoniae strains. Iranian Journal of Basic Medical Sciences, 19:1193-200.

Kamatou G.P.P., Viljoen A.M., van Vuuren S.F., van Zyl R.L. (2006). In vitro evidence of antimicrobial synergy between Salvia chamelaeagnea and Leonotis leonurus. South African Journal of Botany, 72:634-6.

Kelmanson J.E., Jäger A.K., Van Staden J. (2000). Zulu medicinal plants with antibacterial activity. Journal of Ethnopharmacology, 69(3):241-6.

Kotiranta A., Lounatmaa K., Haapsalo M. (2000). Epidemiology and pathogenesis of Bacillus cereus infections. Microbes Infection, 2:189-198.

Lalitha M.K. (2004). Manual on antimicrobial susceptibility testing. Indian Association of Medical Microbiologists, 46.

Levinson W, Jawetz E. (2002). Medical microbiology and immunology: Examination and board review. International. 7th ed., Lange Medical Books/McGraw-Hill, New York.

Liu G., Liang J., Wang X., Li Z. (2011). In vitro synergy of biochanin $A$ and ciprofloxacin against clinical isolates of Staphylococuus aureus. Molecules, 16 (8):6656-66.

Liu, H.; Zhang, W.; Wu, Y.; Sun, L.; Wang, Y.; Liu, Y.; Zhang, X.; Hong, P.; Ji, H. (2017). Synergistic antimicrobial effect and mechanism of lipopeptides and tea polyphenols against Vibrio parahaemolyticus. Food Sciences, 38: 14-19.

Naz, S., Siddiqi, R., Ahmad, S., Rasool, S.A., and Sayeed, S.A.J. (2007). Antibacterial activity directed isolation of compounds from Punica granatum. Journal of Food Science, 72 (9): 3415 .
Olajuyigbe O. O., Afolayan a. J. (2012). Synergistic Interactions of Methanolic Extract of Acacia mearnsii de wild with antibiotics against bacteria of clinical relevance. International journal of molecular sciences, 13(7): 8915-32.

Pagliarulo C., De vito V., Picariello G. (2016). Inhibitory effect of pomegranate (Punica granatum) polyphenol extracts on the bacterial growth and survival of clinical isolates of pathogenic staphylococcus aureus and escherichia coli. Food chemistry, 190: 824-31.

Petersen P.J., Labthavikul P., Jones C.H., Bradford P.A. Kamatou G.P.P. (2006). In vitro antibacterial activities of tigecycline in combination with other antimicrobial agents determined by chequer board and time-kill kinetic analysis. Journal of Antimicrobial Chemotherapy, 57:573-6.

Prasad R.N., Viswanathan S., Devi J.R., Nayak V., Swetha V.C., Archana B.R., Parathasarathy N., Rajkumar J. (2008). Preliminary phytochemical screening and microbial activity of Samaea saman. Journal of Medicinal Plant Research, 2:268-70.

Roberts A.E., Maddocks S.E., Cooper R.A. (2012). Manuka honey is bactericidal against Pseudomonas aeruginosa and results in differential expression of oprF and algD. Microbiology, 158:300513.

Rosas-Burgos E. C., Burgos-Hernández A., Noguera-Artiaga L. (2017). Antimicrobial activity of pomegranate peel extracts as affected by cultivar, Journal of the Science of Food and Agriculture, 97(3): $802-10$.

Rouveix B. (2007). Implications of multiple drug resistant efflux pumps of pathogenic bacteria. Journal of Antimicrobial Chemotherapy, 5(96):1208-9.

Sato Y., Shibata H., Arai T., Yamamoto A., Okimura Y., Arakaki N., Higuti T. (2004). Variation in synergistic activity by flavone and its related compounds on the increased susceptibility of various strains of methicillin-resistant Staphylococcus aureus to $\beta$-lactam antibiotics. International Journal of Antimicrobial Agents, 24:226-33.

Subramaniam P., Dwivedi S., Uma E. and Girish Babu K. L. (2012). Effect of pomegranate and aloe vera extract on streptococcus mutans: An in vitro study, Dental Hypotheses, 3 (3): 99-105.

Tsuchiya H., Sato M., Miyazaki T., Fujiwara S., Tanigaki S., Ohyama M., Tanaka T., Iinuma M. (1996). Comparative study on the antibacterial activity of phytochemical flavonones against methicillin-resistant Staphylococcus aureus, Journal of Ethnopharmacology, 50:27-34.

Usha P.T.A., Jose S., Nisha A.R. (2010). Antimicrobial drug resistance a global concern. Veterinary World, 3:138-9.

Viuda-Martos M., Fernández-López J., Pérez-Álvarez J.A. (2010). Pomegranate and its many functional components as related to human health: a review. Comprehensive Reviews in Food Science and Food Safety, 9:635-54.

Yang Z.C., Wang B.C., Yang X.S., Wang Q., Ran L. (2005). The synergistic activity of antibiotics combined with eight traditional Chinese medicines against two different strains of Staphylococcus aureus. Colloids and Surfaces B, Biointerfaces, 41:79-81. 